\title{
FORMATION OF GRANULATION TISSUE BY DRILLING HOLES IN THE CRANIUM AFTER CHEMICAL SCALP BURNS: A CASE STUDY

\author{
Ali Güneş ${ }^{1}$, Ahmet Erkılıç ${ }^{2}$, Murat Ali Çınar ${ }^{3}$, Sait Bilal $^{4}$
}

\begin{abstract}
Although chemical burns constitute 3\% to 5\% of all burns, they are responsible for 30\% of burn-related deaths. Chemical burns cause protein denaturation in physiological proteins by different mechanisms such as reduction, oxidation, corrosion, purification, salinization, and protoplasmic poisoning. Time is very important in the treatment of chemical burns. Chemical substances should be removed very quickly from the body. Chemical scalp burns (with bones) are a rare injury in clinical practice. In the case of scalp burns, including bones, it becomes an important problem when flab surgeries fail or cannot be performed. This study was planned to examine the formation of granulation tissue by drilling holes in the cranium after chemical scalp burns, and to determine the process of grafting and clinical practice.

A 55-year-old male patient was admitted to the emergency department after a chemical burn (nitric acid). He was admitted to the burn center with $20 \%$ of the total chemical burn being in the third degree, especially on the head and chest area. The patient was treated with debridement. Since the cranial periosteum was burned, the defect was wide and there was a chemical burn for the second time, graft and flap surgeries could not be performed. Multiple holes were drilled on the skull. Approximately a month later, granulation was observed in all holes in the cranium. The granulated areas in the skull were cleaned and debrided. The defect in the cranium was closed with a split thickness graft. Approximately 15 days later, he was discharged from the hospital. Therefore, after exposure to nitric acid, more than half of the scalp was burned to the bone. After the necrotic tissues were cleaned, the skull bones appeared. Since graft and flap surgeries could not be performed, granulation was stimulated on the cranium by opening holes in the skull.
\end{abstract}

UDC Classification: 617, DOI: 10.12955/cbup.v7.1447

Keywords: Chemical burn, granulation, cranium grafting

\section{Introduction}

Although chemical burns constitute $3 \%$ to $5 \%$ of all burns, they are responsible for $30 \%$ of deaths related to burns (Wasiak, 2009; Pegg, 2005; Watson, 2005). Chemical burns are often caused by contact with strong acid and alkaline substances. They are often seen after work accidents, attacks and improper use of cleaning materials (Currei, 1970). Chemical burns cause protein denaturation in physiological proteins by different mechanisms such as reduction, oxidation, corrosion, purification, salinization, and protoplasmic poisoning (Jelenko, 1974; Elijah, 2012).

There is no heat-related damage in chemical burns, it occurs due to the coagulation necrosis formed by the substance when it comes into contactwith tissue (Currei, 1970; Saydjari, 1986). The extent of the damage to the burn area is not known immediately after aThe skin may appear to be intact up to a few days after the burn (Cartotto, 1996; Sawhney, 1989).

Time is very important in the treatment of chemical burns. Chemical substances should be removed very quickly from the body. The effect of chemicalsis reduced on the washing process (this can be described as hydrotherapy). In the local treatment of chemical burns, the purpose should be the dilution of the substance, not the neutralization (Saydjari, 1986). aim isto reduce the effect of the chemical and remove the active substance from the body as soon as possible (Achauer, 1990; Mozingo, 1988). For chemical burns, like other types of burns, liquid-electrolyte and colloid treatment and wound care should be applied according to the degree and extent of the burn.

\section{Case Report}

A 55-year-old male patient was admitted to the emergency department after a chemical burn (nitric acid). He was admitted to the burn center with $20 \%$ total of chemical burn being in the third degree, especially on the head and chest area. It has been understood that the patient was treated because of chemical burn(nitric acid) five years ago. . The patient was treated with debridement. Since the cranial periosteum was burned, the defect was wide and there was a chemical burn for the second time, therefore graft and flap surgeries could not be performed (Figure-1). Ten days after hospital admission, the patient was asked for a neurosurgical consultation and the patient was operated upon. Multiple holes were drilled on the skull. The necrotic bone areas were removed by a pneumatic drill (Figure-2). Ap-

\footnotetext{
125 Aralık State Hospital, Burn Center, Gaziantep, Turkey, op.dr.ag@hotmail.com

225 Aralık State Hospital, Burn Center, Gaziantep, Turkey, aeres57@yahoo.com

${ }^{3}$ Hasan Kalyoncu University, Faculty of Health Sciences, Physiotherapy and Rehabilitation, Gaziantep, Turkey, muratali.cinar@hku.edu.tr

${ }^{4} 25$ Aralık State Hospital, Neurosurgery, Gaziantep, Turkey
} 
proximately a month later, granulation was observed in all holes in the cranium. The granulated areas in the skull were cleaned and debrided. The defect in the cranium was closed by split thickness grafts. Approximately 15 days later, he was discharged from the hospital. (Figure-3).

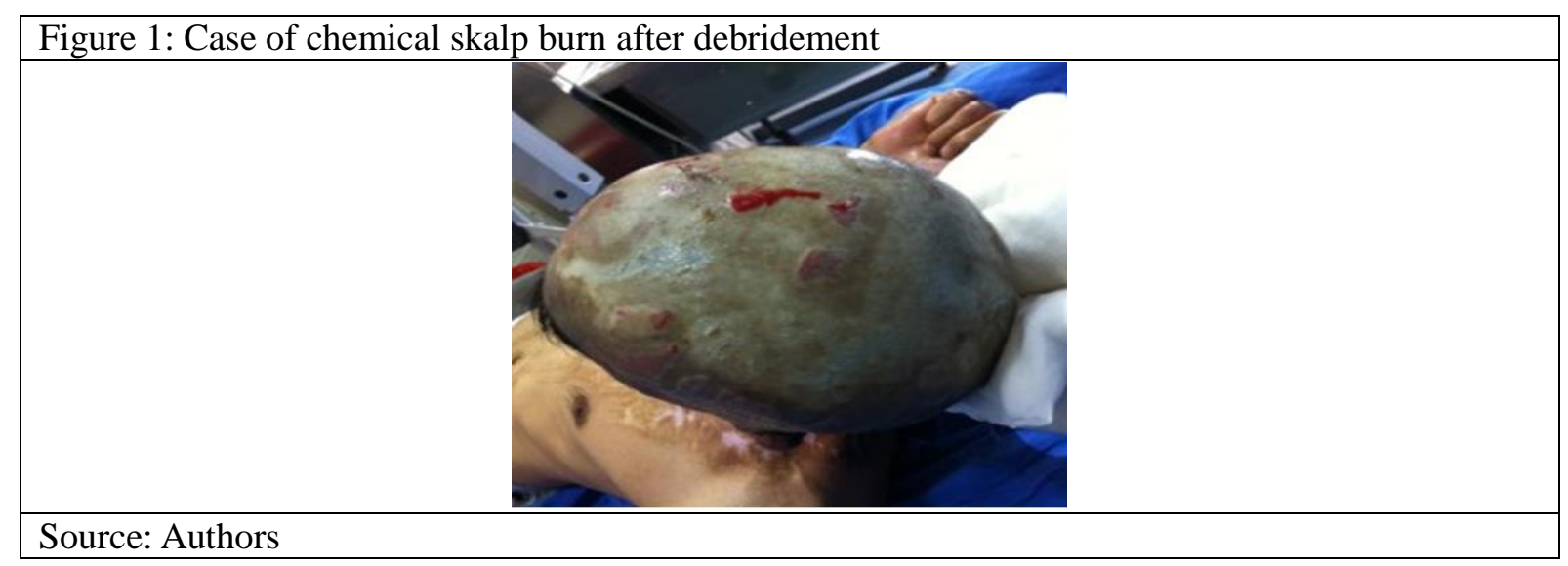

\begin{tabular}{|l|l|l|}
\hline Figure 2: Multiple holes after drilling & \\
\hline & & \\
\hline Source: Authors & & \\
\hline
\end{tabular}

Figire 3: Stage of surgery and grafting. A: Granulation occurred after surgery, B: Granulation in all areas of cranium, C: Split thickness graft after granulation, D: The image of the patient after 3 years from discharge

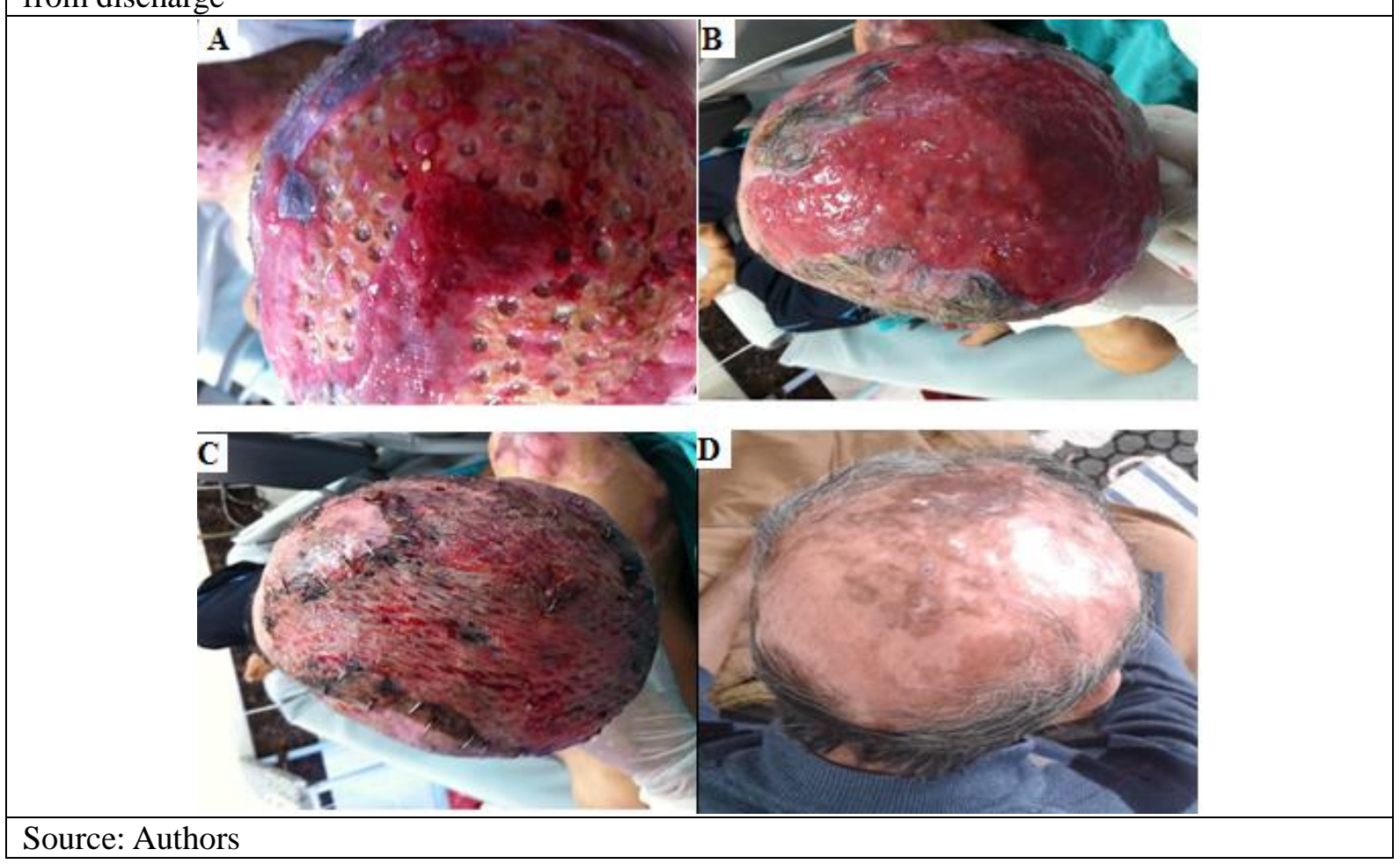




\section{Ethics Approval and Consent to Participate}

Ethical approval was obtained from Hasan Kalyoncu University, Faculty of Health Sciences Ethics Committee. The patient was informed of the nature of the study and a consent form was signed. The patient was made aware of their right to terminate their participation at any time.

\section{Discussion}

In the literature, there were no cases of granulation which was formed by drilling multiple holes in the cranium after a chemical burn to the scalp. However, Furlanetti et al. (2010) reported that a 10-yearold girl who had avulsion of the scalp was re-implanted urgently, multiple openings were made to the skull when granulation occurred when the implant did not hold, and the defect was successfully closed by split-thickness skin graft about one month later.

There are countless methods for reconstructing a burned skull. In small lesions $(<3 \mathrm{~cm})$, primary closure can be performed (Cox, 1999; Ritchie, 1989 ). Split skin grafts can be combined with a gradual procedure after the wound is temporarily closed with the expander method. The first advantage of split skin graft for reconstructing scalp skin is its being technically simple. The disadvantage is that it looks cosmetically bald (bald) compared to the normal region because there is no hair in the graft area. Transplant, progression and rotation flaps were used in the reconstruction of the scalp skin. Orticochea et al. (1967) stated that four-flap scalp reconstructive technique could cover $30 \%$ of cranial defects. In our patient, cranial defect reconstruction could not be performed because the cranium defects were more than $30 \%$.

The expander method is especially useful in scalp reconstruction because the surgeon is given the opportunity to replace a tissue with similar quality and thickness to the missing tissue (Zuker, 1987; Wieslander, 1988). This technique increases the amount of locally available tissue, maintains sensation and protects the hair follicles and additional structures (Austad, 1982). Although the expander technique is the best technique in scalp burns, in our patient skin elasticity was lost because he was exposed to acid more than once. Therefore, the expiratory technique could not be applied to the patient.

Oishi and Luce (1995) recommended that the bone should be protected after removal of the necrotic tissues in the skull and the defect should be closed with a well-vascularized flap. In this way, it was concluded that the flap plays an important role in the prevention of osteomyelitis.

In addition, graft surgery cannot be performed since the bone periosteum was burned in the head burns. A bone defect can be closed with a slide flap after excision of dead tissues in small scalp burns. However, in cases where graft and flap operations cannot be performed in wide cranial burns, it is expected that granulation will be formed by opening numerous holes in the skull. After granulation, the split wound can be closed with a split-thickness graft.

\section{Conclusion}

When it is looked at the literature, research related to chemical burn and its treatment is limited.Therefore, the treatment of cases is difficult. Drilling multiple holes in the cranium is a safe and effective method for treating large scalp burns caused by chemicals. This method can be considered as a good treatment alternative if a skin graft and flap procedure cannot be performed.

\section{References}

Achauer BM (1990) Treatment of chemical burns. Presented at the annual meeting of the American Burn Association, Las Vegas, Nev, Mar. 17,

Austad, E. D., Pasyk, K. A., McClatchey, K. D., \& Cherry, G. W. (1982). Histomorphologic evaluation of guinea pig skin and soft tissue after controlled tissue expansion. Plastic and Reconstructive Surgery, 70(6), 704-710.

Cartotto RC, Peters WJ, Neligan PC, Douglas LG, Beeston (1996) J. Chemical burns. Can J Surg ;39:205-11.

Cox, A. J., Wang, T. D., \& Cook, T. A. (1999). Closure of a scalp defect. Archives of facial plastic surgery, 1(3), 212-215.

Curreri PW, Asch MJ, Pruitt BA (1970). The treatment of chemical burns: specialized diagnostic, therapeutic, and prognostic considerations. Journal of Trauma and Acute Care Surgery, 10(8), 634-642.

Elijah IE, Sanford AP, Lee JO, (2012) Chemical Burns. In: Herndon DN, editor. Total Burns Care. 4th edn. New York: Elsevier;455-60.

Furlanetti, L. L., de Oliveira, R. S., Santos, M. V., Farina, J. A., \& Machado, H. R. (2010). Multiple cranial burr holes as an alternative treatment for total scalp avulsion. Child's Nervous System, 26(6), 745-749.

Jelenko C. (1974). Chemicals that "burn”. Journal of Trauma and Acute Care Surgery, 14(1), 65-72.

Mozingo DW, Smith AA, McManus WF et al (1988) Chemical burns. J Trauma; 28: 642-647 
Oishi, S. N., Luce, E. A. (1995). The difficult scalp and skull wound. Clinics in plastic surgery, 22(1), 51-59.

Orticochea, M. (1967). Four flap scalp reconstruction technique. British journal of plastic surgery, 20, 159-171.

Pegg, S. P. (2005). Burn epidemiology in the Brisbane and Queensland area. Burns, 31(1), S27-S31.

Ritchie, A. J., Rocke, L. G. (1989). Staples versus sutures in the closure of scalp wounds: a prospective, double-blind, randomized trial. Injury, 20(4), 217-218.

Saydjari, R., Abston, S., Desai, M. H., Herndon, D. N. (1986). Chemical burns. The Journal of burn care \& rehabilitation, 7(5), 404-408.

Sawhney, C. P., Kaushish, R. (1989). Acid and alkali burns: considerations in management. Burns, 15(2), 132-134.

Wasiak, J., Spinks, A., Ashby, K., Clapperton, A., Cleland, H., \& Gabbe, B. (2009). The epidemiology of burn injuries in an Australian setting, 2000-2006. Burns, 35(8), 1124-1132.

Watson, W. A., Litovitz, T. L., Rodgers, G. C., Klein-Schwartz, W., Reid, N., Youniss, J., ... \& Wruk, K. M. (2005). 2004

annual report of the American association of poison control centers toxic exposure surveillance system. The American journal of emergency medicine, 23(5), 589-666.

Wieslander, J. B. (1988). Repeated tissue expansion in reconstruction of a huge combined scalp-forehead avulsion injury. Annals of plastic surgery, 20(4), 381-385.

Zuker, R. M. (1987). The use of tissue expansion in pediatric scalp burn reconstruction. The Journal of burn care \& rehabilitation, 8(2), 103-106. 